\title{
Extraction of Silica from Cassava Periderm using Modified Sol-Gel Method
}

\author{
J. A. Adebisi ${ }^{1 *}$, J. O. Agunsoye ${ }^{2}$, S. A. Bello ${ }^{3}$, M. Haris ${ }^{4}$, M. M. Ramakokovhu', M. O. Daramola ${ }^{6}$, S. B. Hassan ${ }^{2}$ \\ ${ }^{1}$ Department of Materials and Metallurgical Engineering, University of Ilorin, Ilorin, Nigeria. \\ ${ }^{2}$ Department of Metallurgical and Materials Engineering, University of Lagos, Akoka, Nigeria. \\ ${ }^{3}$ Department of Materials Science and Engineering, Kwara State University, Malete, Nigeria. \\ ${ }^{4}$ Department of Physics, Karunya University, Karunya Nagar, Coimbatore 641 114, India. \\ ${ }^{5}$ Department of Chemical, Metallurgical and Materials Engineering, Tshwane University of Technology, Pretoria, South Africa. \\ ${ }^{6}$ School of Chemical and Metallurgical Engineering, Faculty of Engineering and the Built Environment, University of the \\ Witwatersrand, Wits 2050, Johannesburg, South Africa.
}

ABSTRACT: Cassava peridem wastes are generated and disposed indiscriminately or burnt due to zero economic value. In this study, modified sol-gel synthesis of amorphous silica nanoparticles from cassava periderm (CP) was investigated. The wastes were pretreated with $\mathrm{HCl}$ to remove soluble metallic impurities. Both treated and untreated $\mathrm{CP}$ flakes were calcined at $700{ }^{\circ} \mathrm{C}$ to obtain their respective ashes. The ashes were leached with $\mathrm{HCl}$ to remove soluble metallic oxides and thereafter sol-gelled to obtain silica gel modified with ethylene glycol. The gel was dried at $80{ }^{\circ} \mathrm{C}$ for 18 hours and then characterized using SEM, EDX, XRD, FT-IR, Raman, TEM and PSA. The SEM micrographs showed that silica modified with ethylene glycol is less agglomerated with higher silica yield and lower particle sizes. All the silica produced showed similar functional groups and non-crystallinity. The silica nanoparticles could be used as starting materials for synthesis of silicon nanoparticles.

KEYWORDS: agricultural waste, cassava periderm, amorphous silica, agglomeration, sol-gel.

[Received October 30 2017; Revised December 22 2017; Accepted March 24 2018]

\section{INTRODUCTION}

Agricultural wastes have been utilized for production of several useful materials to alleviate challenges associated with their disposal. Agricultural wastes have been used for production of solid fuel briquettes, adsorbents, cellulose, activated carbon, silica, silicon, refectory and ceramic products, livestock feed, inhibitors, biofuels, construction materials, lignin, and composite reinforcement (Agunsoye et al., 2017, Agbenyeku and Aneke, 2014, Heuzé et al., 2014, Aigbodion et al., 2010, Kalderis et al., 2008, Kurniawan et al., 2011, Ki et al., 2013, Liu et al., 2014, Odusote et al., 2016, Achinivu et al., 2014, Adepoju et al., 2016, Venkateswaran et al., 2012, Le Normand et al., 2014). Most often, these wastes are generated and disposed indiscriminately or burnt, resulting in environmental pollution with adverse effects on climate (IEA, 2016). Interestingly, Nigeria is the largest producer of cassava, and thus generates cassava periderm as a complete waste with no known value (Adebisi et al., 2017a).

Silica occurs naturally as quartz with largest percentage in the earth crust (Zulehner et al., 1997). It is crystalline in nature with low reactivity. Amorphous silica on the other

*Corresponding author's e-mail address: adebisijeleel@gmail.com hand finds applications in many areas owing to its advantage of being highly reactive. Silica has been utilized for several applications across many industries such as pharmaceuticals, archaeology, biomedical, electronics and feedstock in silicon production (birth of semiconductor revolution) (Wikipedia, 2018). It has been used as intensive blue light emitter, fining agent in food industry, powder flow agent in pharmaceutical industry, extra-terrestrial particles collectors, DNA and RNA extractors, hard abrasives in toothpaste, inhibitor of human breast cancer, desiccant, oil absorption, capacitors, hydrogen storage and silicon production (Yu et al., 1998, Castellari et al., 2001, Forny et al., 2007, Chattoraj et al., 2011, Westphal et al., 2014, Tan and Yiap, 2009, Joiner, 2009, Joshi et al., 2008, Negre et al., 2016, Mohammad-Rezaei and Razmi, 2016, Yuvakkumar et al., 2014b, Konwar and De, 2014, Villareal et al., 2013).

The non-crystalline type has been synthesized from sodium silicate (Sudirmana et al., 2012), water glass (Lee et al., 2007) and tetraethoxylsilane (TEOS) (Liu et al., 2006). It has also been produced from agricultural wastes (Zemnukhova et al., 2012, Mohanraj et al., 2012, Adepoju et al., 2016, Vaibhav et al., 2015). The methods used for the synthesis from agricultural wastes involve combination of doi: http://dx.doi.org/10.4314/njtd.v15i2.4 
processes like acid treatment, partial burning (charring), burning, calcination, leaching, enzymatic treatment (Decker et al., 2007), pyrolysis, hydrolysis and sol-gel (Nayak and Bera, 2012, Mansha et al., 2011). Extensive review on production of silica from agricultural wastes has been reported by the authors (Adebisi et al., 2017a). Adepoju et al. (2016) synthesized silica nanoparticle from cassava periderm with average grain size of $62.69 \mathrm{~nm}$ using conventional solgel method. The particles were reported to be lumpy and observed to be highly agglomerated. This work investigated the effect of acid pre-treatment and addition of ethylene glycol as capping agent in modified sol-gel method for control of particle size and agglomeration.

\section{MATERIALS AND METHODS}

\section{A. Materials}

Cassava periderm (CP) used was extracted from cassava purchased from traders at Better Life market, Isale-Osun, Osogbo, Osun State. Reagents used include sodium hydroxide $(\mathrm{NaOH})$, hydrochloric acid $(\mathrm{HCl})$ and ethylene glycol $(\mathrm{CH} 2 \mathrm{OH} . \mathrm{CH} 2 \mathrm{OH})$. All reagents used were analytical grades from NICE Chemicals ltd., Kerala, India except $\mathrm{NaOH}$ purchased from Rankem Laboratory, Mumbai, India. Double distilled water (DDW) was used during all processes. Munkcell Ahlstrom filter paper (Grade 389, Ø125 mm; Whatman No 41 equivalent) was used with vacuum filter for all filtration processes.

\section{B. Methods}

Cassava periderm was prepared as described in Adebisi et al. (2017b). The cassava periderm was treated in $0.1 \mathrm{M}$ $\mathrm{HCl}$ at $45 \pm 5{ }^{\circ} \mathrm{C}$ for $90 \mathrm{~min}$ to remove some soluble compounds. The flakes were then rinsed with DDW five times to remove the leachate. The untreated and treated CP flakes were oven dried at $105{ }^{\circ} \mathrm{C}$ for 5 hours and then labelled untreated cassava periderm (UCP) and treated cassava periderm (TCP), respectively. UCP and TCP were calcined separately at $700{ }^{\circ} \mathrm{C}$ for 4 hours to obtain their respective ashes, labelled untreated cassava periderm ash (UCPA) and treated cassava periderm ash (TCPA).

$500 \mathrm{ml}$ of $0.54 \mathrm{M} \mathrm{HCl}$ was measured in two $1000 \mathrm{ml}$ Erlenmeyer flasks and heated to $42.5 \pm 5{ }^{\circ} \mathrm{C}$ on magnetic stirrer hot plates. $25 \mathrm{~g}$ each of UCPA and TCPA were separately leached in the warm $\mathrm{HCl}$ solution for $75 \mathrm{~min}$, stirred at $600 \mathrm{rpm}$. The mixtures were filtered and residues rinsed with DDW five times to remove traces of the acid. The residues were then oven dried at $80{ }^{\circ} \mathrm{C}$ for 18 hours and labelled leached untreated cassava periderm ash (LUCPA) and leached treated cassava periderm ash (LTCPA).

$500 \mathrm{ml}$ of $2.0 \mathrm{M} \mathrm{NaOH}$ was heated to boiling point before introduction of $15 \mathrm{~g}$ of each LUCPA and LTCPA, in different $1000 \mathrm{ml}$ Erlenmeyer flasks. The mixture was magnetically stirred for 2 hours at $700 \mathrm{rpm}$. The concentration was kept constant by addition of DDW to maintain the volume. The mixture was allowed to cool before filtration with Whatman No 41-filter paper to get sodium silicate (see Equation 1). LUCPA and LTCPA sodium silicates were separately stirred at $900 \mathrm{rpm}$ at room temperature and titrated with $1.0 \mathrm{M} \mathrm{HCl}$ to precipitate silica. The mixtures were allowed to age for 18 hours before filtration to obtain silica gels. The gels were rinsed five times to remove $\mathrm{NaCl}$ (see Equation 2). For the modified sol-gel approach, $20 \mathrm{v} / \mathrm{v} \%$ ethylene glycol (EG) was added to freshly prepared $500 \mathrm{ml}$ LTCPA sodium silicate prior to the titration. Rinsing was repeated five times before $50 \%$ EG was stirred with the rinsed gel before final filtration.

The three gels were oven-dried at $80{ }^{\circ} \mathrm{C}$ for 24 hours. Modified gel was thereafter dried in two stages at $130{ }^{\circ} \mathrm{C}$ for $60 \mathrm{~min}$ to remove water of hydration and then $250{ }^{\circ} \mathrm{C}$ for another $60 \mathrm{~min}$ to vapourize EG. All the silicas were labelled LUCPA silica, LTCPA silica and silica (EG). Silica (EG) was finally thermally treated at $1000{ }^{\circ} \mathrm{C}$ for 2 hours to examine the crystalline phases present.

$\mathrm{SiO}_{2(\text { s,impureash })}+2 \mathrm{NaOH}_{(a q)} \rightarrow \mathrm{Na}_{2} \mathrm{SiO}_{3(a q)}+\mathrm{H}_{2} \mathrm{O}_{(l)}$
$\mathrm{Na}_{2} \mathrm{SiO}_{3(a q)}+2 \mathrm{HCl}_{(a q)} \rightarrow \mathrm{SiO}_{2(s, g e l)}+2 \mathrm{NaCl}_{(a q)}+\mathrm{H}_{2} \mathrm{O}_{(l)}$

\section{Characterization}

Thermogravimetric analysis (TGA) was carried out to investigate the effect of acid pre-treatment on thermal stability of CP. Scanning electron microscopy (SEM), energy dispersive X-ray spectroscopy (EDS) and X-ray diffractometry (XRD) were used to investigate morphology, elemental composition and phases of compounds, respectively, in all the samples. Silica (EG) was finally characterized with Fourier transform infrared spectroscopy (FT-IR), Raman spectroscopy, transmission electron microscopy (TEM) and particle size analysis (PSA) for its surface chemistry, functionality, morphology and particles sizes (and distribution), respectively.

\section{RESULTS AND DISCUSSION}

\section{A. Thermogravimetric Analysis (TGA)}

Figure 1 shows the TGA curves for UCP and TCP thermally decomposed in Nitrogen atmosphere. Both samples showed significant mass loss as the operating temperature increased from room temperature to $945^{\circ} \mathrm{C}$. TCP is thermally more stable due to removal of some phases during the acid treatment (Carmona et al., 2013). The first stage of thermal degradation that occurred at $105{ }^{\circ} \mathrm{C}$ could be attributed to dehydration of the flakes and mass loss of 6.7 and $4.3 \%$ for UCP and TCP, respectively. Further loss at temperatures between $105{ }^{\circ} \mathrm{C}$ and $223{ }^{\circ} \mathrm{C}$ could be associated with removal of water of crystallization and some light volatiles (Adebisi et al., 2017b).

The second stage of significant mass loss of about $40 \%$ (between $362{ }^{\circ} \mathrm{C}$ and $453{ }^{\circ} \mathrm{C}$ ) is the same for both UCP and TCP. This shows that the hemicelluloses are unaffected by the acid treatment. TCP gave a distinctive cellulose removal between 362 and $453{ }^{\circ} \mathrm{C}$, followed by carbonization stage that indicate decomposition of lignin. There exists overlap in 
cellulose and lignin decompositions in UCP up to $783{ }^{\circ} \mathrm{C}$. The remaining chars left are 16.8 and $3.1 \%$ for TCP and UCP, respectively. The higher residue in TCP could be due to loss of some lignocellulosic phases during acid treatment (Rahman et al., 1997, Carmona et al., 2013). Oxidative thermal decomposition of cassava periderm has been reported with optimum calcination temperature of $700{ }^{\circ} \mathrm{C}$ against higher conditions observed in the Nitrogen environment (Adebisi et al., 2017b).

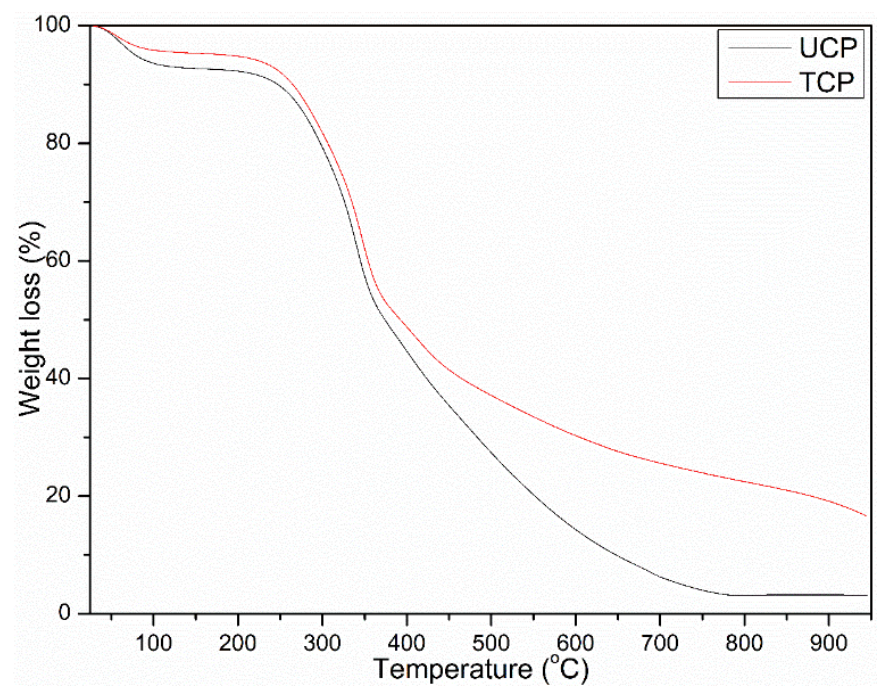

Figure 1: Thermogravimetric Analysis of untreated Cassava Periderm (UCP) and treated Cassava Periderm (TCP).

\section{B. XRD Analysis}

X-ray diffraction patterns for UCP and TCP with further processing conditions are shown in Figure 2. The patterns for UCP and TCP indicate amorphous phases with few crystalline phases at $24.7,26.9,35.2,44,64.3$ and 77.5 diffraction angles with significant difference at 24.7and 26.9. Calcination of both UCP and TCP suppressed their amorphic natures with identifiable crystalline phases. The effect of acid treatment is prominent at this stage since fewer peaks shown for TCPA confirm removal of some phases during acid pretreatment. Leaching of UCPA and TCPA with $\mathrm{HCl}$ further purified the residues. The XRD peaks detected correlate with Joint Committee on Powder Diffraction Standards (JCPDS) reference numbers of $\mathrm{SiO} 2$ (78-1254), KAlSi3O8 (83-1604), $\mathrm{NaAl}(\mathrm{SiO} 3) 2 \cdot 3 \mathrm{H} 2 \mathrm{O}$ (03-0234) for LUCPA while only $\mathrm{SiO} 2$ and CaAlAlSiO6 (70-2129) are observed for LTCPA. Also, crystallinity of the residues is improved by the postcalcination acid treatments.

Silicas obtained from LUCPA, LTCPA and silica (EG) after several rinsing with DDW and drying (up to $250{ }^{\circ} \mathrm{C}$ for silica with EG) showed similar amorphous natures as shown in Figure 3. Amorphous nature of silicas obtained by chemical methods has been reported (Pijarn et al., 2010, Adebisi et al., 2017c). Ethylene glycol retained some $\mathrm{NaCl}$, even after several rinsing, as observed from the XRD peaks before vapourization of the EG. Annealing of the silica at $1273 \mathrm{~K}$ transformed the amorphous silica to crystalline silica with JCPDS reference code 82-0512 which is found to be cristobalite with tetragonal crystal system (Yuvakkumar et al., 2012, Venkateswaran et al., 2012, Haastrup et al., 2016).
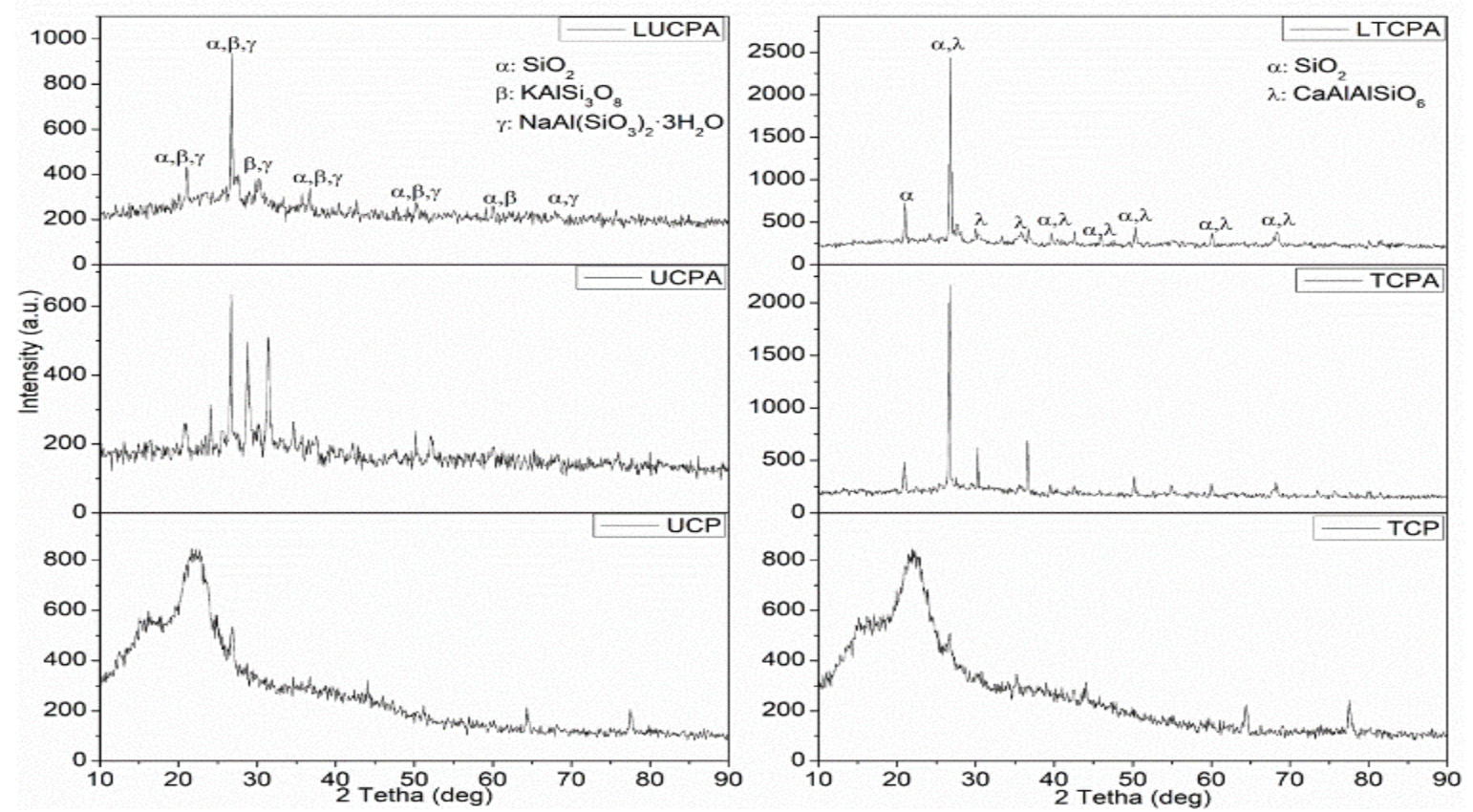

Figure 2: XRD of untreated and treated Cassava Periderm (UCP and TCP), Cassava Periderms calcined at $700{ }^{\circ} \mathrm{C}\left(\mathrm{UCPA}^{\circ}\right.$ and TCPA) and Acid Leached Chars (LUCPA and LTCPA). 
This enables easy calculation of crystal size of amorphous powders using Scherrer equation. The crystallite size of the silica produced is given in Table 1 with average crystal size of $16.98 \mathrm{~nm}$.

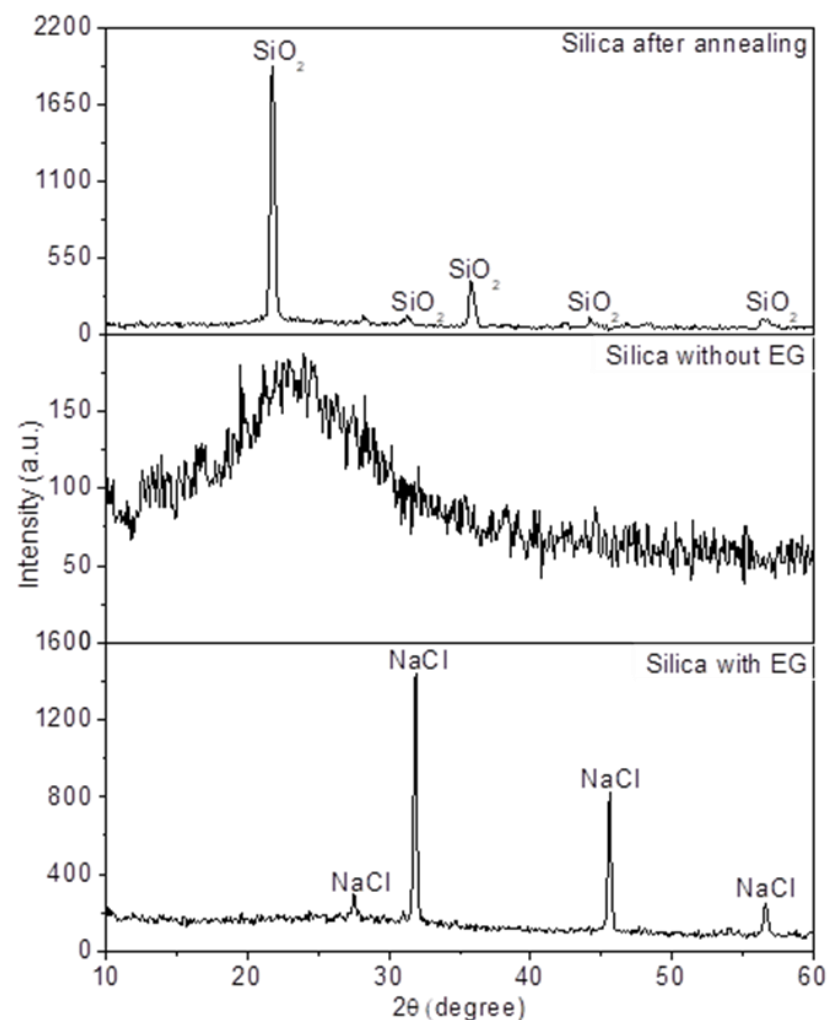

Figure 3: Silicas obtained without/with Ethylene Glycol (EG) and after annealing at $1273 \mathrm{~K}$.

\section{Scanning Electron Microscopy (SEM)}

Figure 4 shows the SEM micrographs of cleaned CP (a1), treated CP (b1), calcined UCP (a2) and TCP (b2), leached UCPA (a3) and TCPA (b3). It is observed that UCP and TCP have nonporous and bulky tissues. Calcination of both UCP and TCP produced fine particles of UCPA and TCPA but TCPA is less fragmented due to its higher thermal stability. This is more pronounced after leaching of UCPA and TCPA as could be observed in Figure 4 ( $a 3$ and b3).
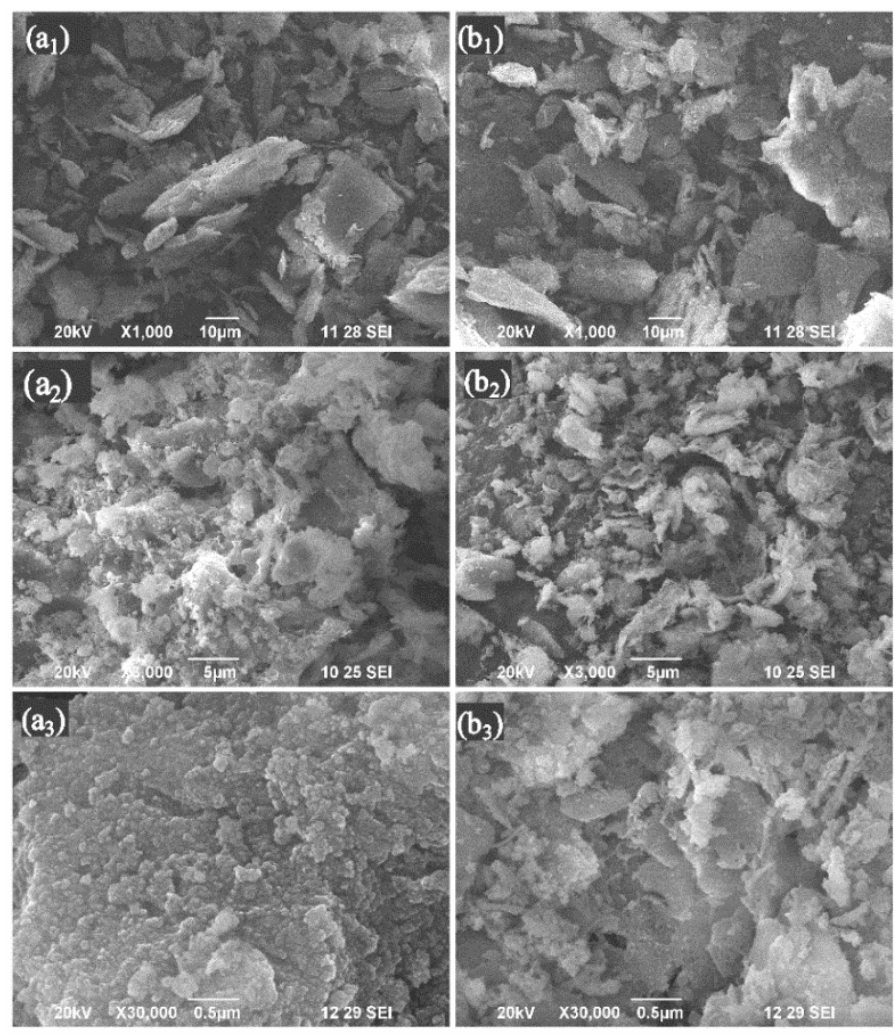

Figure 4: SEM Micrographs of (a) untreated CP, (b) $\mathrm{HCl}$ treated CP for (1) as received/treated, (2) calcined at $700{ }^{\circ} \mathrm{C}$, and (3) $\mathrm{HCl}$ leached calcines.

The SEM micrographs of silicas produced are shown in Figure 5. Degree of agglomeration is highly influenced by processing conditions of the silicas. LUCPA silica is extremely agglomerated Figure 5(a) but reduced in the silica produced from pre-treated CP (Figure 5(b)). Drying silica (EG) at $105^{\circ} \mathrm{C}$ doesn't remove the ethylene glycol that seems to bind the silica particles together as shown in Figure 5(c). Vapourization of ethylene glycol above its boiling point, at $250{ }^{\circ} \mathrm{C}$ left dispersed small agglomerates (Figure 5(d)). The morphology of the amorphous silicas produced revealed no definite shape in all the processing routes. This implies that particles formed are still agglomerated irrespective of methods of production.

Table 1: Crystal Size of Silica produced using Scherrer Equation.

\begin{tabular}{rcccc}
\hline No. & $\begin{array}{c}\text { Peak pos. } \\
{[\mathbf{2 \theta} \text { (degree) }]}\end{array}$ & $\begin{array}{c}\text { FWHM } \\
{[\mathbf{2 \theta} \text { (degree) }]}\end{array}$ & $\begin{array}{c}\text { Rel. Int. } \\
{[\%]}\end{array}$ & Crystallite size (nm) \\
\hline 1 & 21.7779 & 0.2952 & 100.00 & 27.4 \\
2 & 28.2853 & 0.5904 & 2.41 & 14.6 \\
3 & 31.2592 & 0.5904 & 2.62 & 14.8 \\
4 & 35.8209 & 0.3936 & 17.39 & 21.2 \\
5 & 44.3416 & 0.5904 & 2.65 & 14.5 \\
6 & 56.5653 & 0.9600 & 3.36 & 9.4 \\
\hline
\end{tabular}




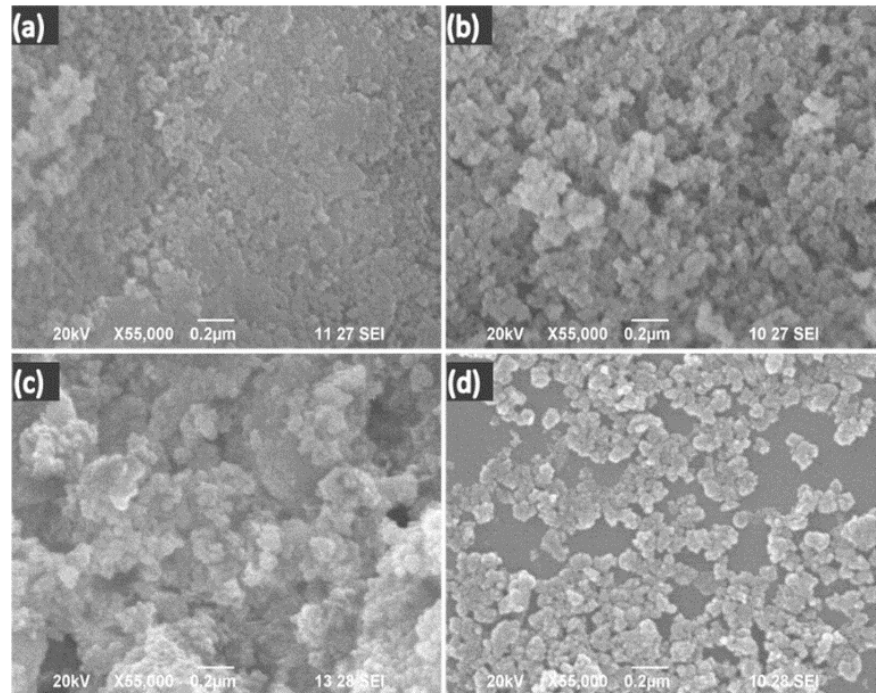

Figure 5: SEM Micrographs of Silica obtained from (a) asreceived $\mathrm{CP}$, (b) $\mathrm{HCl}$ treated $\mathrm{CP}$, (c) Ethylene Glycol Modified Silica, and (d) Silica after Vaporization of EG

\section{Energy Dispersive Spectroscopy}

Figure 6 shows the elemental composition of $\mathrm{CP}$ through the various processes such as acid pre-treatment, calcination and post calcination acid leaching. Silicon was not detected in UCP (Figure 6(a1)) which improved by acid leaching to a slight detectable level in TCP (Figure 6(b1)). Calcination produced residues composed mainly of elements $\mathrm{Na}, \mathrm{Mg}, \mathrm{Al}$, $\mathrm{Si}, \mathrm{K}, \mathrm{Ca}$ and $\mathrm{Fe}$. The high oxygen proportions indicate presence of oxides of the elements. Figure $6(\mathrm{a} 2$ and $\mathrm{b} 2)$ revealed higher silicon percent in both UCPA and TCPA.

Silicon percent increased after post calcination treatment and removal of soluble impurities. Both acid pre-treatment and post calcination leaching are effective in removing $\mathrm{Na}$ completely while post calcination treatment is effective for $\mathrm{Mg}$ removal. The acid treatments reduced $\mathrm{Mg}, \mathrm{K}$ and $\mathrm{Ca}$ while $\mathrm{Al}$ and $\mathrm{Fe}$ are unaffected. Acid treatments have been reported to improve quality of silica produced from agricultural wastes (Chandrasekhar et al., 2005). Highest silicon proportions are obtained after post calcination treatments of with/without acid pre-treatments [Figure 6(a3 and b3)].

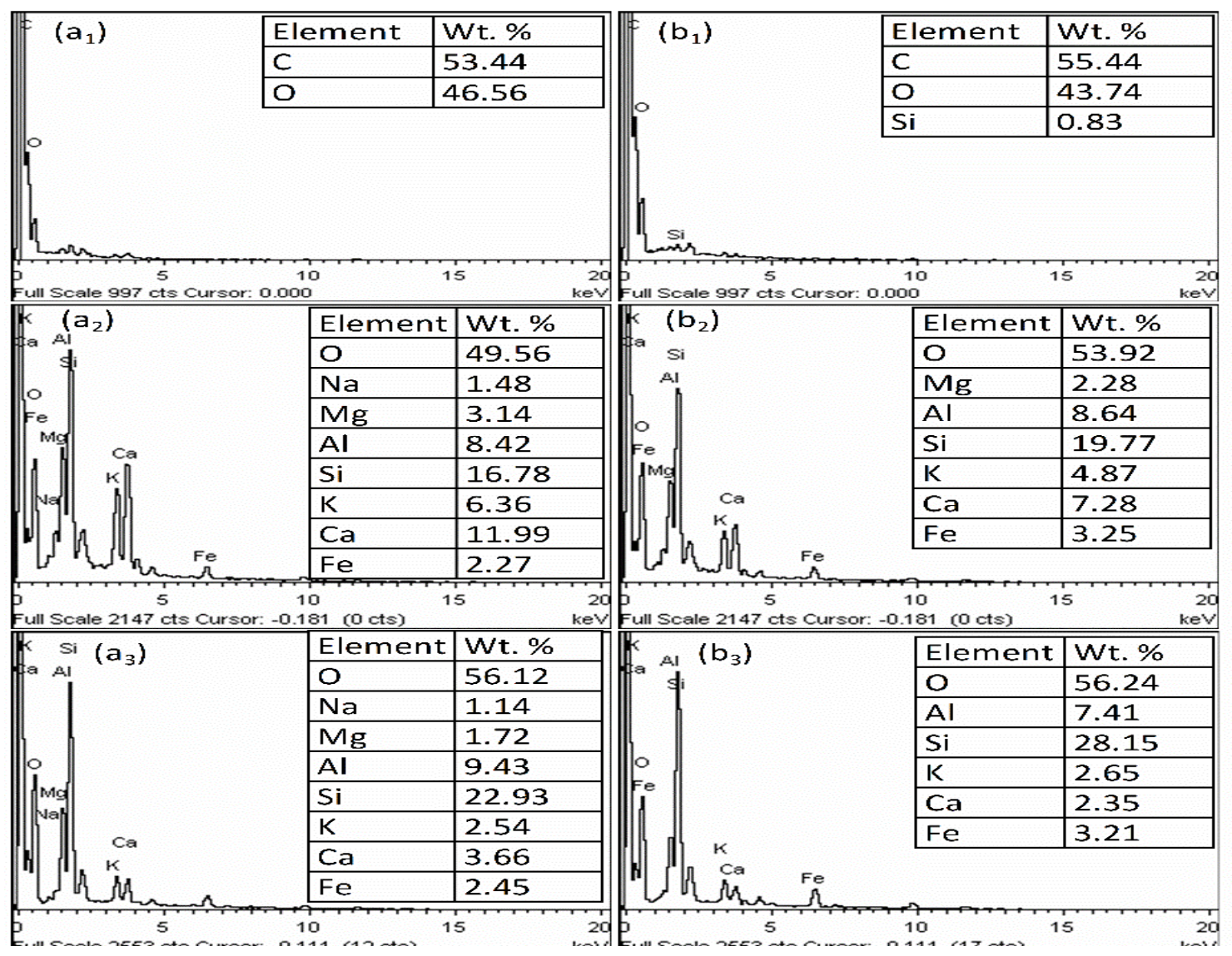

Figure 6: Energy Dispersive X-Ray Spectra and Composition of (a) untreated CP, (b) HCl treated CP for (1) as received/treated, (2) calcined at $700{ }^{\circ} \mathrm{C}$, and (3) $\mathrm{HCl}$ leached calcines. 
Table 2 shows the chemical compositions of silica obtained using three different routes. Presence of $\mathrm{Na}$ could be attributed to those retained from unrinsed $\mathrm{NaCl}$ from precipitation process. Al present in the modified silica is very low compared to other silicas produced. Both acid pretreatment and introduction of ethylene glycol improved the purity of silica. Chakraverty et al. (1988) has reported effectiveness of acid treatments on purity of silica.

Table 2: Chemical Composition of Silica Produced from asreceived/treated CP and Ethylene Glycol (EG) Modified Sol-Gel Precipitated Silica.

\begin{tabular}{cccc}
\hline Elements & $\begin{array}{c}\text { LUCPA } \\
\text { silica }\end{array}$ & $\begin{array}{c}\text { LTCPA } \\
\text { silica }\end{array}$ & Silica (EG) \\
\hline $\mathbf{O}$ & 54.70 & 54.95 & 56.48 \\
$\mathbf{N a}$ & 10.03 & 5.69 & 2.52 \\
$\mathbf{A l}$ & 10.97 & 9.15 & 3.01 \\
$\mathbf{S i}$ & 24.30 & 29.75 & 36.89 \\
$\mathbf{K}$ & ND & 0.47 & 0.09 \\
$\mathbf{C a}$ & ND & ND & 0.08 \\
$\mathbf{F e}$ & ND & ND & 0.65 \\
$\mathbf{C u}$ & ND & ND & 0.29 \\
\hline
\end{tabular}

\section{E. Functional groups analysis in modified silica by FT-IR}

The FT-IR spectrum of silica produced by morphological modification with ethylene glycol is shown in Figure 7. Silica is characterized by band between 400 and $1300 \mathrm{~cm}^{-1}$ (Carmona et al., 2013, Espíndola-Gonzalez et al., 2010, Liou, 2004, Liou and Yang, 2011, Rafiee et al., 2012).

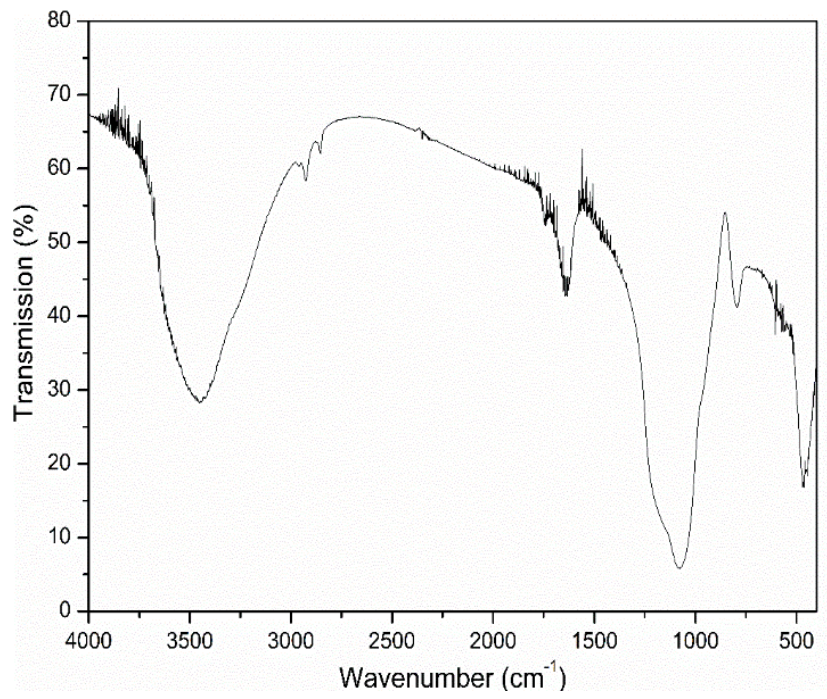

Figure 7: FT-IR Spectrum of Silica (EG) after drying at $250{ }^{\circ} \mathrm{C}$.
The spectra from prepared silica exhibits bands at 448, 796 and $1085 \mathrm{~cm}^{-1}$, corresponding to characteristics rocking of the Si-O bond, its bending and symmetric and asymmetric stretching of Si-O-Si bond, respectively (Espíndola-Gonzalez et al., 2010).

Drying the samples at $65{ }^{\circ} \mathrm{C}$ left the samples with $\mathrm{OH}$ and $\mathrm{H}-\mathrm{O}-\mathrm{H}$ bonds for silanol and adsorbed water (Carmona et al., 2013). The band at $1642 \mathrm{~cm}^{-1}$ corresponds to $\mathrm{H}-\mathrm{O}-\mathrm{H}$ twisting while band spreading from 2600 to $3800 \mathrm{~cm}^{-1}$ represent stretching vibrations of the surface silanols $(\mathrm{Si}-\mathrm{OH})$ groups excited by hydrogen bonds of either water adsorbed or those between Si-O molecules (Carmona et al., 2013, Rafiee et al., 2012).

\section{F. Raman Spectroscopy}

Figure 8 presents the Raman spectra of silica modified with ethylene glycol. Raman bands between 487 and $600 \mathrm{~cm}^{-1}$ presents Raman spectra of $\mathrm{SiO} 2$ (Gottardi et al., 1984). The stretching band of silanol (Si-OH) is at $980 \mathrm{~cm}^{-1}$ but spreads across 800 and $1100 \mathrm{~cm}^{-1}$ (Gottardi et al., 1984, Yuvakkumar et al., 2014a, McMillan and Remmele, 1986). Hydroxyl (OH) bending and stretching band peaks are at $1630 \mathrm{~cm}^{-1}$ and near $3450 \mathrm{~cm}^{-1}$. The weak band near $2350 \mathrm{~cm}^{-1}$ may correspond to silanol groups intra-tetrahedrally hinged by hydrogen bonding across SiO4 (McMillan and Remmele, 1986). The absorption bands for $\mathrm{Si}-\mathrm{H}$ is also in the range from 2100 to $2400 \mathrm{~cm}^{-1}$ (Vella et al., 2011).

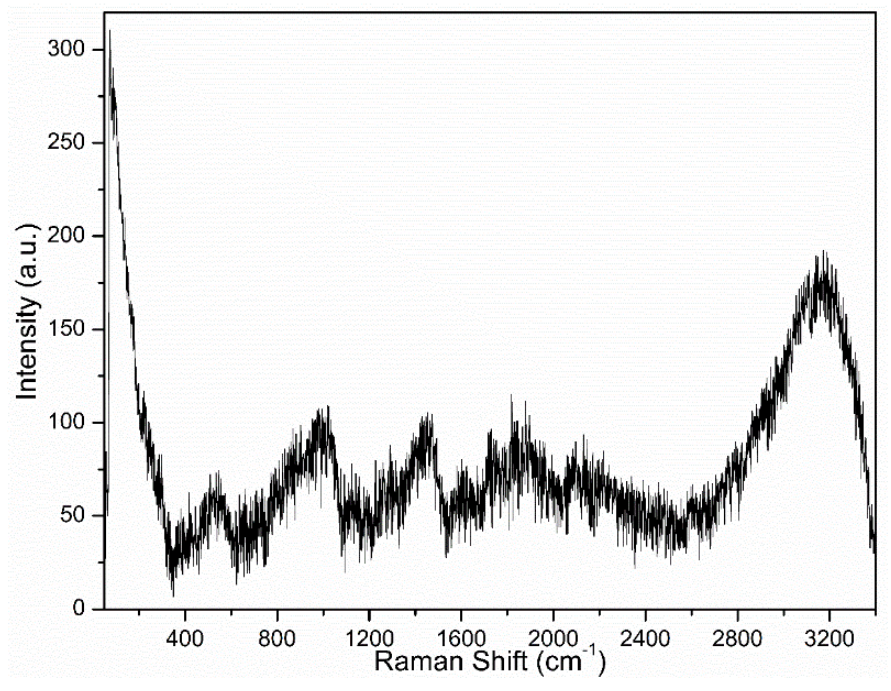

Figure 8: Raman Spectrum of Silica Modified with Ethylene Glycol.

\section{G. Analysis of particle size and distribution (TEM and PSA)}

Figure 9 shows TEM image of silica (EG) produced and dried at $250{ }^{\circ} \mathrm{C}$. All the particles were found to be below 100 $\mathrm{nm}$ but with some agglomerated spherical morphology apparently in the upper part of the image. Figure 10 presents the particle size distribution of the silica nanoparticles produced. The maximum distribution was found between 3.12 to $50.75 \mathrm{~nm}$. These values are in agreement with those obtained from Scherrer crystallite sizes. 


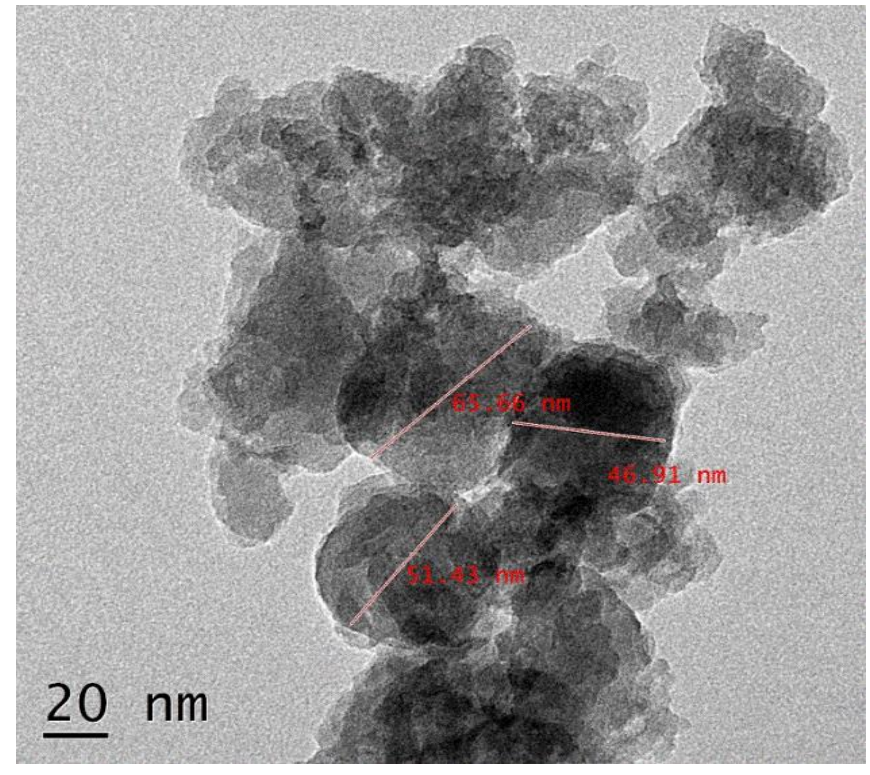

Figure 9: TEM Image of Nano Silica (EG) produced after drying at $250{ }^{\circ} \mathrm{C}$.

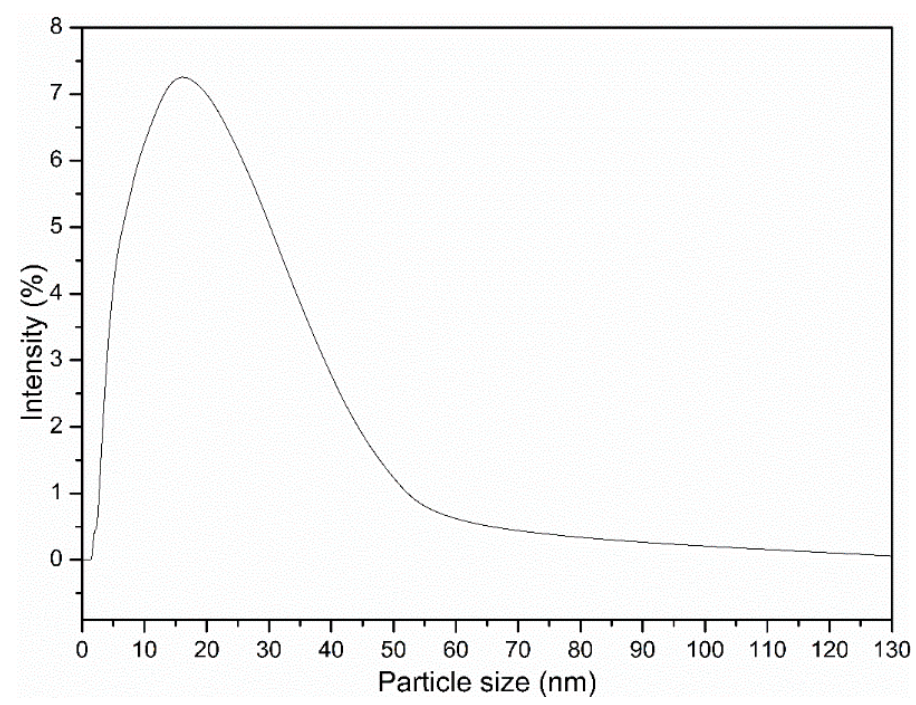

Figure 10: Particle Size Distribution of Nano Silica (EG) after drying at $250{ }^{\circ} \mathrm{C}$.

\section{CONCLUSION}

Silica has been produced from cassava periderm using three different routes. Acid treatments before and after calcination were found to be effective for reducing or eliminating soluble metallic impurities. Silica obtained from acid pre-treatment, post-calcination treatment and ethylene glycol modified sol-gel methods are found to yield higher purity silica particles that are in nano range from 3.12 to $50.75 \mathrm{~nm}$.

\section{ACKNOWLEDGEMENTS}

The authors acknowledge Institute of NanoEngineering Research (INER), Tshwane University of Technology, Pretoria, South Africa for making available their facilities for this research. Special thanks for exceptional support received from Mr. Bamidele Lawrence Bayode and his team members. The cooperation enjoyed from Mr. MBS Pravin and Mr. A. Raja of Department of Nanoscience and Technology, Karunya University, Tamil Nadu, India, is highly appreciated. This work was supported by NAM S\&T Centre Research Training Fellowship for Developing Country Scientists (RTFDCS) [No. NAM - 05/74/2016].

\section{REFERENCES}

Achinivu, E. C.; R. M. Howard, G. Li, H. Gracz and W. A. Henderson. (2014). Lignin Extraction from Biomass with Protic Ionic liquids. Green Chemistry, 16: 1114-1119.

Adebisi, J. A.; J. O. Agunsoye, S. A. Bello., I. I. Ahmed, O. A. Ojo and S. B. Hassan. (2017). Potential of Producing Solar Grade Silicon Nanoparticles from Selected Agro-Wastes: A Review. Solar Energy, 142: 68-86.

Adebisi, J. A.; J. O. Agunsoye, S. A. Bello, F. O. Kolawole, M. M. Ramakokovhu, M. O. Daramola and S. B. Hassan. (2017). Extraction of Silica from Sugarcane Bagasse, Cassava Periderm and Maize Stalk: Proximate Analysis and Physico-Chemical Properties of Wastes. Waste and Biomass Valorization. $1-13$.

Adepoju, A. D.; J. A. Adebisi. J. K. Odusote, I. I. Ahmed and S. B. Hassan. (2016). Preparation of Silica from Cassava Periderm. The Journals of Solid Waste Technology and Management, 42 (3): 216-221.

Agbenyeku, E. O. E. and Aneke, I. F. (2014). Prolonged Curing of Green Concrete from Domestically Derived Cassava Peels Ash (DDCPA) and Laterite. International Journal of Scientific and Engineering Research, 5 (1): 900-905.

Agunsoye, J. O.; S. A. Bello and L. O. Adetola (2017). Experimental Investigation and Theoretical Prediction of Tensile Properties of Delonix Regia Seed Particle Reinforced Polymeric Composites. Journal of King Saud UniversityEngineering Sciences 2017: $1-13$.

Aigbodion, V. S.; S. B. Hassan, T. Ause and G. B. Nyior. (2010). Potential Utilization of Solid Waste (Bagasse Ash). Journal of Minerals and Materials Characterization \& Engineering, 9 (1): 67-77.

Carmona, V. B.; R. M. Oliveira, W. T. L. Silva, L. H. C. Mattoso and J. M. Marconcini. (2013). Nanosilica from Rice Husk: Extraction and Characterization. Industrial Crops and Products, 43 (1): 291-296.

Castellari, M.; A. Versari, A. Fabiani, G. P. Parpinello and S. Galassi. (2001). Removal of Ochratoxin A in Red Wines by Means of Adsorption Treatments with Commercial Fining Agents. Journal of Agricultural and Food Chemistry, 49 (8): 3917-3921. 
Chakraverty, A.; P. Mishra and H. D. Banerjee. (1988). Investigation of Combustion of Raw and AcidLeached Rice Husk for Production of Pure Amorphous White Silica. Journal of Materials Science, 23: 21-24.

Chandrasekhar, S.; P. N. Pramada and L. Praveen. (2005). Effect of Organic Acid Treatment on the Properties of Rice Husk Silica. Journal of Materials Science, 40 (24): 6535-6544.

Chattoraj, S.; L. Shi and C. C. Sun. (2011). Profoundly Improving Flow Properties of a Cohesive Cellulose Powder by Surface Coating with Nano-Silica through Comilling. Journal of Pharmaceutical Sciences, 100 (11): 4943-4952.

Decker, S. R.; J. Sheehan, D. C. Dayton, J. J. Bozell, W. S. Adney, B. Hames, S. R. Thomas, R. L. Bain, S. Czernik, M. Zhang and M. E. Himmel. (2007). Biomass Conversion. In: Kent, J. A. (ed.) Kent and Riegel's Handbook of Industrial Chemistry and Biotechnology. 1449 - 1548. 11th edition. Springer, New York.

Espíndola-Gonzalez, A.; A. L. Martínez-Hernández, C. Angeles-Chávez, V. M. Castaño and C. Velasco-Santos. (2010). Novel Crystalline SiO2 Nanoparticles via Annelids Bioprocessing of Agro-Industrial Wastes. Nanoscale Research Letters, 5 (9): 1408-1417.

Forny, L.; I. Pezron, K. Saleh, P. Guigon and L. Komunjer. (2007). Storing Water in Powder Form by SelfAssembling Hydrophobic Silica Nanoparticles. Powder Technology, 171: 15-24.

Gottardi, V.; M. Guglielmi, A. Bertoluzza, C. Fagnano and M. A. Morelli. (1984). Further Investigations on Raman Spectra of Silica Gel evolving toward Glass. Journal of Non-Crystalline Solids, 63 (1 - 2): 71-80.

Haastrup, S.; D. Yu and Y. Yue. (2016). Impact of Surface Impurity on Phase Transitions in Amorphous Micro Silica. Journal of Non-Crystalline Solids, 450: 42-47.

Heuzé, V.; G. Tran, H. Archimède, C. Régnier, D. Bastianelli and F. Lebas. (2016). Cassava Peels, Cassava Pomace and Other Cassava By-Products. Available online at: http://www.feedipedia.org/node/526. Accessed on February 13, 2017.

IEA. (2016). Key World Energy Statistics. International Energy Agency. Available online at: http://www.elearning.humnet.unipi.it/mod/resource/view.php ?id=20526. Accessed on September 4, 2017.

Joiner, A. (2009). A Silica Toothpaste containing Blue Covarine: A New Technological Breakthrough in Whitening. International Dental Journal, 59 (5): 284-288.

Joshi, H. H.; R. E. Gertz, M. Da Gloria Carvalho and B. W. Beall. (2008). Use of Silica Desiccant Packets for Specimen Storage and Transport to Evaluate Pneumococcal Nasopharyngeal Carriage Among Nepalese Children. Journal of Clinical Microbiology, 46 (9): 3175-3176.

Kalderis, D.; S. Bethanis, P. Paraskeva and E. Diamadopoulos. (2008). Production of Activated Carbon from Bagasse and Rice Husk by a Single-Stage Chemical Activation Method at Low Retention Times. Bioresource Technology, 99 (15): 6809-6816.

Ki, O. L.; A. Kurniawan, C. X. Lin, Y. H. Ju and S. Ismadji. (2013). Bio-Oil from Cassava Peel: A Potential
Renewable Energy Source. Bioresource Technology, 145, 157-161.

Konwar, R. J. and De, M. (2014). Synthesis of High Surface Area Silica Gel Templated Carbon for Hydrogen Storage Application. Journal of Analytical and Applied Pyrolysis, 107: 224-232.

Kurniawan, A.; A. N. Kosasih, J. Febrianto, Y.-H. Ju, J. Sunarso, N. Indraswati and S. Ismadji. (2011). Evaluation of Cassava Peel Waste as Lowcost Biosorbent for Ni-sorption: Equilibrium, Kinetics, Thermodynamics and Mechanism. Chemical Engineering Journal, 172: 158-166.

Le Normand, M.; R. Moriana and M. Ek. (2014). Isolation and Characterization of Cellulose Nanocrystals from Spruce Bark in a Biorefinery Perspective. Carbohydrate Polymers, 111: 979-987.

Lee, S.; Y. C. Cha, H. J. Hwang, J.-W. Moon and I. S. Han. (2007). The Effect of $\mathrm{pH}$ on the Physicochemical Properties of Silica Aerogels Prepared by an Ambient Pressure Drying Method. Materials Letters, 61: 3130-3133.

Liou, T.-H. (2004). Preparation and Characterization of Nano-Structured Silica from Rice Husk. Materials Science and Engineering, 364 (1): 313-323.

Liou, T.-H. and Yang, C.-C. (2011). Synthesis and Surface Characteristics of Nanosilica Produced from AlkaliExtracted Rice Husk Ash. Materials Science and Engineering, B 176 (7): 521-529.

Liu, Y.; H. Zhou, Z. Shen, L. Li, X. Zhou, P. Sun, Z. Yuan, T. Chen, B. Li and D. Ding. (2006). Synthesis of Nanoporous Silica with Interior Composite Cells with Synthetic Block Copolypeptide as Template. Chinese Science Bulletin, 51 (4): 493-497.

Liu, Z.; A. Quek and R. Balasubramanian. (2014). Preparation and Characterization of Fuel Pellets from Woody Biomass, Agro-Residues and their Corresponding Hydrochars. Applied Energy, 113: 1315-1322.

Mansha, M.; S. H. Javed, M. Kazmi and N. Feroze. (2011). Study of Rice Husk Ash as Potential Source of Acid Resistance Calcium Silicate. Advances in Chemical Engineering and Science, 1: 147-153.

Mcmillan, P. F. and Remmele, R. L. (1986). Hydroxyl Sites in SiO2 Glass: A Note on Infrared and Raman Spectra. American Mineralogist, 71 (5-6): 772-778.

Mohammad-Rezaei, R. and Razmi, H. (2016). Preparation and Characterization of Reduced Graphene Oxide Doped in Sol-Gel Derived Silica for Application in Electrochemical Double-Layer Capacitors. International Journal of Nanoscience and Nanotechnology, 12 (4):233-241.

Mohanraj, K.; S. Kannan, S. Barathan and G. Sivakumar. (2012). Preparation and Characterization of Nano SiO2 from Corn Cob Ash by Precipitation Method. Optoelectronics and Advanced Materials - Rapid Communications, 6 (3-4): 394 - 397.

Nayak, J. P. and Bera, J. (2012). Bioactivity Characterization of Amorphous Silica Ceramics Derived from Rice Husk Ash. Silicon, 4 (1): 57-60.

Negre, L.; B. Daffos, P.-L. Taberna and P. Simon. (2016). Silica-Based Ionogel Electrolyte for Electrical Double Layer Capacitors. The Electrochemical Society, Meeting Abstracts, 7: 952-952. 
Odusote, J. K.; D. O. Owalude, S. J. Olusegun and R. A. Yahya. (2016). Inhibition Efficiency of Moringa Oleifera Leaf Extract on the Corrosion of Reinforced Steel Bar in $\mathrm{HCl}$ Solution. West Indian Journal of Engineering, 38 (2): 64.

Pijarn, N.; A. Jaroenworaluck, W. Sunsaneeyametha and R. Stevens. (2010). Synthesis and Characterization of Nanosized-Silica Gels formed under Controlled Conditions. Powder Technology, 203 (3): 462-468.

Rafiee, E.; S. Shahebrahimi, M. Feyzi and M. Shaterzadeh. (2012). Optimization of Synthesis and Characterization of Nanosilica Produced from Rice Husk (A Common Waste Material). International Nano Letters, 2 (1): $29-37$.

Rahman, I. A.; J. Ismail and H. Osman. (1997). Effect of Nitric Acid Digestion on Organic Materials and Silica in Rice Husk. Journal of Materials Chemistry, 7 (8): 1505-1509.

Sudirman, S.; M. Anggaravidya, E. Budianto and I. Gunawan. (2012). Synthesis and Characterization of Polyester-Based Nanocomposite. Procedia Chemistry, 4: 107 -113 .

Tan, S. C. and Yiap, B. C. (2009). DNA, RNA, and Protein Extraction: The Past and The Present. Journal of Biomedicine and Biotechnology. Article ID: 574398, 1 - 10.

Vaibhav, V.; U. Vijayalakshmi and S. M. Roopan. (2015). Agricultural Waste as a Source for the Production of Silica Nanoparticles. Spectrochimica Acta Part A: Molecular and Biomolecular Spectroscopy, 139: 515-520.

Vella, E.; G. Buscarino, G. Vaccaro and R. Boscaino. (2011). Structural Organization of Silanol and Silicon Hydride Groups in the Amorphous Silicon Dioxide Network. The European Physical Journal B, 83 (1): 47.

Venkateswaran, S.; R. Yuvakkumar and V. Rajendran. (2013). Nano Silicon from Nano Silica Using Natural Resource (Rha) for Solar Cell Fabrication. Phosphorus, Sulfur, and Silicon and the Related Elements, 188 (9): 1178-1193.

Villareal, M.; L. Bernabe and M. Gliceria. (2013). Extraction and Characterisation of Silica Powder from Rice Hull Ash and its Efficiency in Oil Absorption. Asia Pacific
Journal of Science, Mathematics and Engineering, 1 (2): 65 68.

Westphal, A. J., H. A. Bechtel, F. E. Brenker, A. L. Butterworth, G. Flynn, D. R. Frank, Z. Gainsforth, J. K. Hillier, F. Postberg, A. S. Simionovici, V. J. Sterken, R. M. Stroud, C. Allen, D. Anderson, A. Ansari, S. Bajt, R. K. Bastien, N. Bassim, J. Borg, J. Bridges, D. E. Brownlee, M. Burchell, M. Burghammer, H. Changela, P. Cloetens, A. M. Davis, R. Doll, C. Floss, E. Grün, P. R. Heck, P. Hoppe, B. Hudson, J. Huth, B. Hvide, A. Kearsley, A. J. King, B. Lai, J. Leitner, L. Lemelle, H. Leroux, A. Leonard, R. Lettieri, W. Marchant, L. R. Nittler, R. Ogliore, W. J. Ong, M. C. Price, S. A. Sandford, J.-A. S. Tresseras, S. Schmitz, T. Schoonjans, G. Silversmit, V. A. Solé, R. Srama, F. Stadermann, T. Stephan, J. Stodolna, S. Sutton, M. Trieloff, P. Tsou, A. Tsuchiyama, T. Tyliszczak, B. Vekemans, L. Vincze, J. Von Korff, N. Wordsworth, D. Zevin and M. E. Zolensky. (2014). Final Reports of the Stardust Interstellar Preliminary Examination. Meteoritics \& Planetary Science, 49 (9): 1720-1733.

Wikipedia (2018). Silicon dioxide [Online]. Wikipedia, The Free Encyclopedia. . Available: https://en.wikipedia.org/w/index.php?title=Silicon_dioxide \& oldid=832361775 [Accessed 7 May 2018 22:16 UTC].

Yu, D. P.; Q. L. Hang, Y. Ding, H. Z. Zhang, Z. G. Bai, J. J. Wang, W. Qian, G. C. Xiong and S. Q. Feng. (1998). Amorphous Silica Nanowires: Intensive Blue Light Emitters. Applied Physics Letters, 73 (21): 3076-3078.

Yuvakkumar, R.; V. Elango, V. Rajendran and N. Kannan. (2014). High-Purity Nano Silica Powder from Rice Husk using A Simple Chemical Method. Journal of Experimental Nanoscience, 9 (3): 272-281.

Yuvakkumar, R.; A. J. Nathanael, V. Rajendran and S. I. Hong. (2014). Rice Husk Ash Nanosilica to Inhibit Human Breast Cancer Cell Line (3T3). Journal of Sol-Gel Science and Technology, 72 (1): 198-205.

Zemnukhova, L. A.; A. E. Panasenko, G. A. Fedorishcheva, A. M. Ziatdinov, N. V. Polyakova and V. G. Kuryavyi. (2012). Properties of Silicon Prepared from Plant Raw Materials. Inorganic Materials, 48 (10): 971-976. 